\title{
En forglemmelig julegavehandel
}

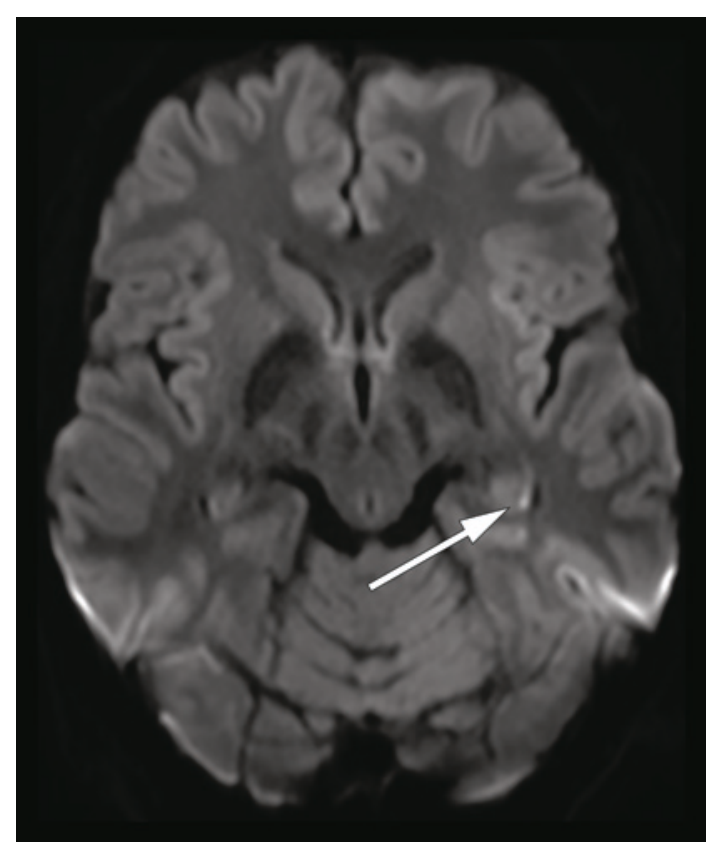

En frisk mann i 40-årene skulle ut for å handle julegaver. På kjøreturen hjemmefra merket han at han fikk problemer med hukommelsen. Gaver som han tidligere hadde kjøpt, kunne han ikke huske hvor han hadde gjort av. Han fortalte at han hadde stoppet bilen flere ganger for å søke på internett på smarttelefonen etter «hukommelsestap», uten at han i ettertid kunne huske søkeresultatet. Han kom hjem med minne om bare bruddstykker av handleturen og en innpakket julegave med uvisst innhold.

Ved klinisk undersøkelse i akuttmottaket ble det, utover anterograd amnesi, ikke funnet aktuelle nevrologiske utfall, og CT caput viste normale forhold. Ved videre undersøkelser to dager senere var det normalt EEG, uten tegn til epileptisk aktivitet. På diffusjonsvektet $\mathrm{MR}$ cerebrum så man et $2 \mathrm{~mm}$ stort område med diffusjonsforandringer i caudadelen av venstre hippocampus (pil). Slike subtile diffusjonsforandringer i hippocampus er typisk for transitorisk global amnesi (TGA) (1).

Dette er et isolert amnesisyndrom med plutselig oppstått anterograd og i varierende grad retrograd amnesi som varer i opptil 24 timer. En rekke hypoteser om hva som kan ligge bak har vært foreslått, som migrene, fokal iskemi, venestase og epilepsi, men den eksakte patofysiologien bak tilstanden er ukjent. Mentalt stress og Valsalva-manøvre i forkant av amnesien er beskrevet i noen studier (1). Diagnosen stilles klinisk ut fra typisk sykehistorie og eksklusjon av aktuelle differensialdiagnoser. Ved vår avdeling utfører vi rutinemessig utredning med EEGog MR-undersøkelse med tanke på tilstander som iskemi i bakre kretsløp og epilepsi. Det er ingen spesifikk behandling for enkeltepisoder. Residivfaren er lav, og tilstanden er ikke forbundet med økt risiko for cerebrovaskulære hendelser (1).

Vår pasient valgte, for spenningens skyld, å vente til julaften for å se hva han hadde kjøpt som gave. Julefreden kunne senke seg da det viste seg at den riktige julegaven var kommet i hus.

Pasienten har gitt samtykke til at artikkelen blir publisert.

\section{Sverre Myren}

sverre@myren.nu

Titto T. Idicula

Avdeling for nevrologi og klinisk nevrofysiologi

\section{Kjell Arne Kvistad}

Klinikk for bildediagnostikk

St. Olavs hospital
Sverre Myren (f. 1986) er lege i spesialisering i nevrologi.

Forfatter har fylt ut ICMJE-skjemaet og oppgir ingen interessekonflikter.

Titto T. Idicula (f. 1974) er ph.d., spesialist i nevrologi og overlege.

Forfatter har fylt ut ICMJE-skjemaet og oppgir ingen interessekonflikter.

Kjell Arne Kvistad (f. 1960) er dr.med., spesialist i radiologi og seksjonsoverlege.

Forfatter har fylt ut ICMJE-skjemaet og oppgir ingen interessekonflikter.

\section{Litteratur}

1. Bartsch T, Deuschl G. Transient global amnesia: functional anatomy and clinical implications. Lancet Neurol 2010; 9: 205-14.

Mottatt 30.1. 2015, første revisjon innsendt 6.3. 2015, godkjent 3.4. 2015. Redaktør: Lise Mørkved Helsingen. 